\title{
DNA Fingerprinting
}

National Human Genome Research Institute (NHGRI)

\section{Source}

National Human Genome Research Institute (NHGRI). DNA Fingerprinting.

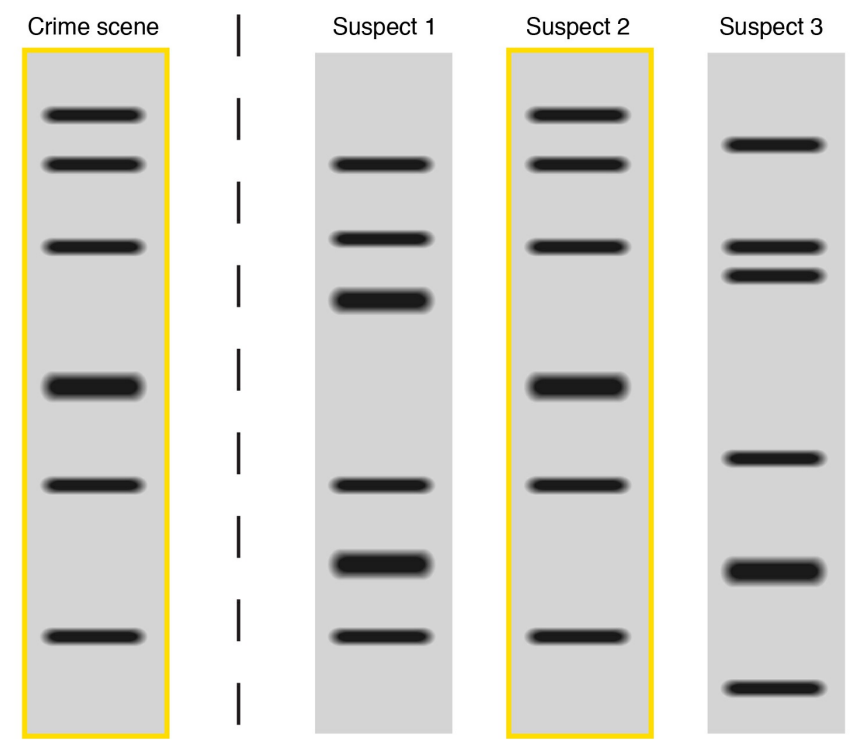

DNA fing erprinting is a laboratory technique used to establish a link between biological evidence and a suspect in a criminal investigation. A DNA sample taken from a crime scene is compared with a DNA sample from a suspect. If the two DNA profiles are a match, then the evidence came from that suspect. Conversely, if the two DNA profiles do not match, then the evidence cannot have come from the suspect. DNA fingerprinting is also used to establish paternity. 